W. F. J. Baeyens (ed.), Trace Metals in the Westerschelde Estuary.

(C)1998 Kluwer Academic Publishers. Printed in Belgium.

\title{
General description of the Scheldt estuary
}

\author{
Willy Baeyens ${ }^{1}$, Bert van Eck ${ }^{2}$, Claude Lambert ${ }^{3}$, Roland Wollast ${ }^{4} \&$ Leo Goeyens ${ }^{1}$ \\ ${ }^{1}$ Department of Analytical Chemistry, Free University of Brussels, Pleinlaan 2, 1050 Brussels, Belgium \\ ${ }^{2}$ Dienst Getijdewateren, Rijksinstituut voor Kust en Zee, Rijkswaterstaat, 4330 EA Middelburg, the Netherlands \\ ${ }^{3}$ Centre National de la Recherche Scientifique (CNRS), 91198 Gif Sur Yvette CEDEX, France \\ ${ }^{4}$ Laboratory of Oceanology, Université Libre de Bruxelles, 1050 Brussels, Belgium
}

Key words: Scheldt estuary, description, hydrology, sedimentation, oxygen profiles, productivity

\begin{abstract}
A general description of the Scheldt estuary, including the hydrology, the sediment transport, the productivity and the biodegradation with respect to their influence on the trace metal behaviour in the Scheldt estuary, is given.

The river basin can be divided in several sections according to their morphological, hydrodynamical and sedimentary properties. The zone from $\mathrm{km} 78$ to 55 , which corresponds roughly with the salinity zone from 2 to $10 \mathrm{psu}$, is the zone of high turbidity, high sedimentation and of oxygen depletion, especially in the summer period. That area is called the geochemical filter because the solid/dissolved distribution of the trace metals is controlled by redox, adsorption/desorption, complexation and precipitation/coprecipitation processes. The sedimentation rate in that area is estimated at $280 \mathrm{Mkg} \mathrm{y}^{-1}$.

In the downstream estuary the phytoplankton activity increases due to the restoration of oxygen and to the much lower turbidity values. That area is called the biological filter because incorporation of trace metals by the plankton communities lowers the trace metal concentrations during the productivity period, while transformation of metal species, especially observed with mercury, occurs during that period too.
\end{abstract}

\section{Introduction}

Like other branches of the Zeeland Delta, the Scheldt estuary fulfils numerous and diverse ecological functions. Total productivity is elevated (Saeijs, 1977) and it is not restricted to the lowest trophic level (higher plants and algae). Secondary production (e.g. zooplankton and shrimps) as well as production of higher trophic levels (e.g. benthic organisms and fish) are significant due to the availability of large amounts of detritus. Moreover, it is quite possible that secondary production is more important than primary production, and that the Scheldt ecosystem showed this feature already in the past.

Benthic organisms contribute largely to the total biomass. Especially the populations on tidal flats and sand plates are a food supply for wintering and migratory stilt-birds but also for ducks. Additionally, the Scheldt estuary serves as a nursery room for demersal fish species such as sole. The pronounced productivity makes the Scheldt an important 'natural resource'.

The species diversity per surface unit is relatively low, but the diversity in the whole estuary is fairly high. This results from the presence of many different environmental types (from fresh water over brackish to marine water types), each of them contributing to the species diversity. Generally, the number of individuals of each species is high, as a result of the high food abundance and the fact that in a given salinity range some species have a favourable, competitive position.

The estuary includes many wetlands and marshes (called schorren and polders in Dutch), Saeftinge and the Ballastplaat being the most important ones. These wetlands are very different, not only geomorphologically, but also with respect to their bottom compositions and plant communities. The qualitative and quantitative vegetation composition differ from one marsh to the other according to the salinity gradient (Saeijs, 
1977). All marshes together determine the diversity in the vegetation along the estuary.

Pollution by toxic metals is one of the major threats to the estuarine ecosystem. Concentrations of dissolved $\mathrm{Pb}, \mathrm{Hg}, \mathrm{Zn}, \mathrm{Cu}$ and $\mathrm{Cd}$ in the coastal estuarine water mass are about 2 times higher than in the marine water mass of the Belgian coastal zone, which is a part of the Southern Bight of the North Sea (Baeyens et al., 1987), and an order of magnitude higher than ocean values. In the Scheldt estuary itself, the heavy metal concentrations are still significantly higher than in the coastal estuarine water mass (Baeyens et al., 1998: see related paper on 'Sea inputs'). Therefore, a better understanding of the respective biogeochemical cycles of heavy metals in the Scheldt estuary with emphasis on the basic governing processes is essential. Amongst the major estuarine processes are the geophysical (water and sediment circulation) and the biological ones (production and biodegradation). Human activities such as discharging of liquid waste and dredging of sludge, are superimposed on the natural processes and, moreover interfere with them. Four aspects make the Scheldt estuary very peculiar and distinct from other estuaries:

(1) the Scheldt is a tide-governed estuary due to the low river flow leading to large residence times;

(2) the upper estuary receives large inputs of biodegradable organic matter inducing anoxic conditions in the water column during summer;

(3) considerable and direct supply of toxic pollutants occurs in the upper estuary as a result of the diverse activities by the industrial park around Antwerp;

(4) the anoxic zone, the area of pollutant inputs and the zone of maximum turbidity coincide geographically, making it very difficult to distinguish between their individual effects on the metal distribution and behaviour.

In this paper hydrology, sediment transport, production and biodegradation are discussed with respect to their possible influence on the trace metal behaviour in the Scheldt.

\section{General description of the Scheldt river basin}

The river Scheldt (Figure 1) is a lowland-river, which takes its rise in the northern part of France (St. Quentin), and flows into the North Sea near Vlissingen (the Netherlands). The total catchment area is $2210^{3}$ $\mathrm{km}^{2}$. The total length of the river is $355 \mathrm{~km}$, the fall over the total river length is at most 100 meters and the mean depth of the Scheldt estuary is about $10 \mathrm{~m}$.
The river Scheldt as well as all its branches are rain-fed. The discharge of these rivers varies considerably with minimal discharges occurring in summer and autumn, and maximum ones in winter and spring. During winter and spring, the lower riverine part from Gent to Antwerp is a tidal fresh water river. During summer and autumn, on the contrary, when the discharge of the river is reduced, the water becomes brackish between Antwerp and the Rupel mouth.

In the total river basin of the Scheldt live approximately 7 million people. Urban areas with population densities of over 1000 inhabitants per $\mathrm{km}^{2}$ are found near Lille (France), Gent, Brussels and Antwerp. The largest industrial areas are concentrated near Lille, Antwerp, along the canal from Gent to Terneuzen, and near Vlissingen. The river Scheldt and its branches are used as a major drain for industrial and domestic wastes. A substantial part of these is not treated in a waste water treatment plant. This gives rise to very poor water quality in the larger part of the river and the eastern part of the estuary.

Valuable natural areas, some of them are protected natural reserves, are situated in the estuarine part of the basin and along the tributaries. In the estuarine part of the basin the intertidal areas are very valuable, e.g. the fresh, brackish and salt water marshes.

\section{Hydrological description}

Four sections can be distinguished in the Scheldt river basin:

- the non-tidal fresh water river corresponding to the upper-Scheldt and a considerable part of the branches;

- the mostly fresh water tidal river extending from Gent to Rupelmonde with the lower parts of some branches;

- the upper estuary (brackish) or the Sea Scheldt between Rupelmonde and the Belgian-Dutch border; and

- the lower estuary (brackish and salt) called the Western Scheldt.

The predominant factors determining the hydrological characteristics of the Scheldt river are the fresh water flow rate and the tidal influence.

\section{Fresh water flow}

The mean discharge rate of the Scheldt, determined at Schelle (90 km from the mouth), amounted to $104 \mathrm{~m}^{3}$ 


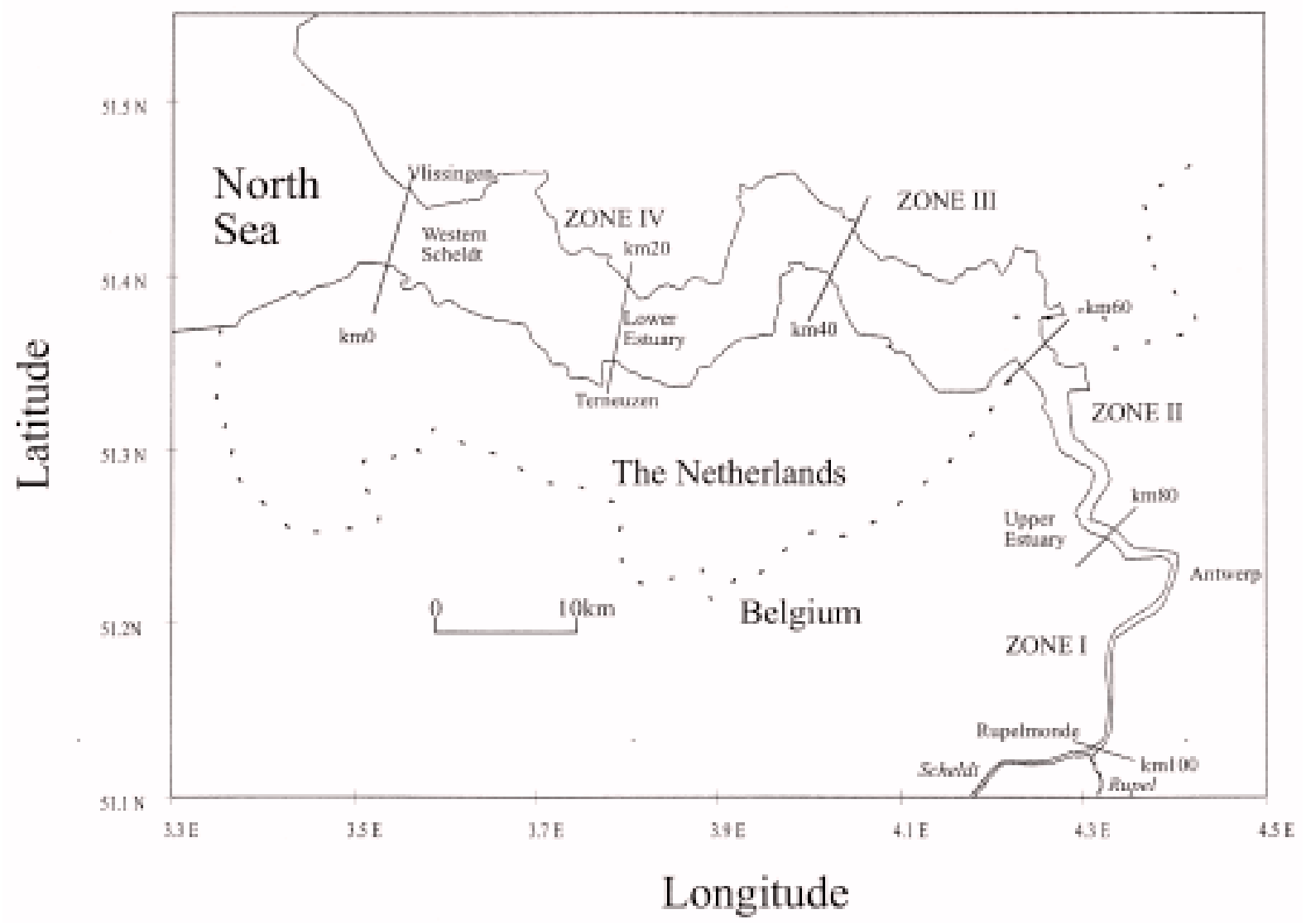

Figure 1. Map of the Scheldt Estuary. Lower estuary (km 0-km 60). Upper estuary (km 60-km 100).

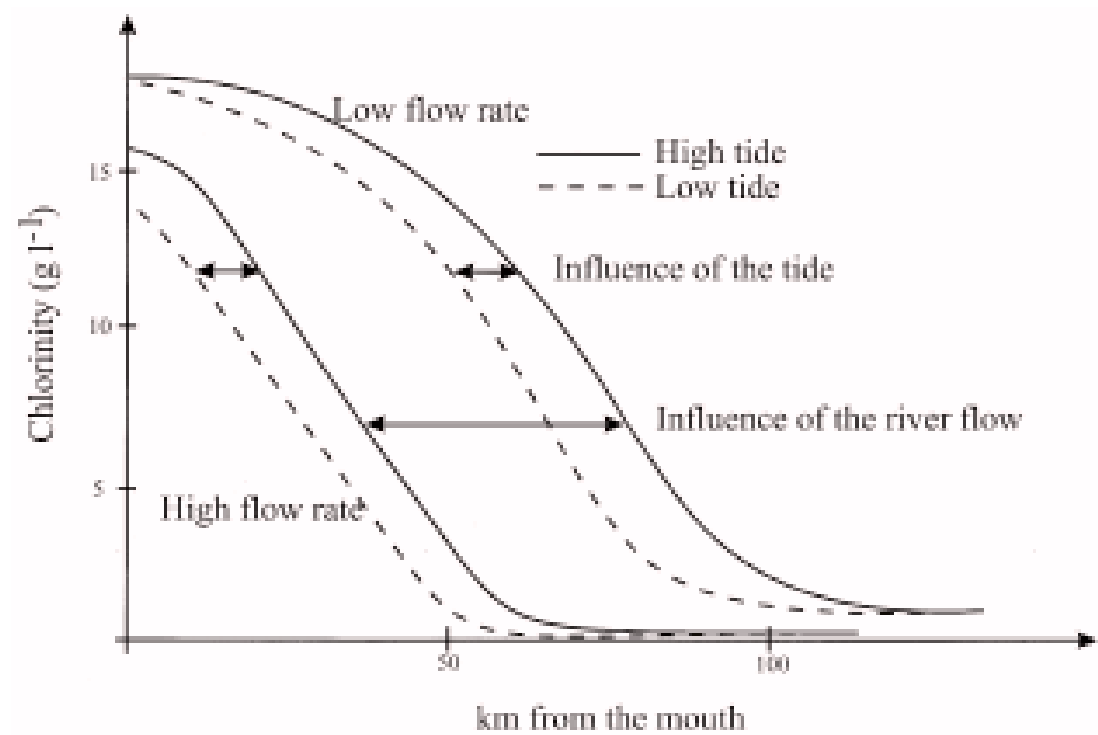

Figure 2. The influence of river flow and tide on the salinity profiles. 
$\mathrm{s}^{-1}$ for the period 1949-1986 (Pers. commun., The Ministry of Public Works). However, since the Scheldt is a typical rain-river, the actual discharge rate is highly dependent on the season. Over the total catchment area about $30 \%$ of the rainfall is drained into the surface water, but in densely populated areas such as Brussels and Antwerp this value increases to $45 \%$.

During winter, the average discharge rate amounts to $180 \mathrm{~m}^{3} \mathrm{~s}^{-1}$ with exceptional values up to $600 \mathrm{~m}^{3} \mathrm{~s}^{-1}$. Average summer values decrease to $60 \mathrm{~m}^{3} \mathrm{~s}^{-1}$ with minimal values down to $20 \mathrm{~m}^{3} \mathrm{~s}^{-1}$. The major tributaries are the Scheldt river, the Dender, the Durme, and the Rupel (including Nete, Zenne and Dijle) accounting respectively for about 27, 6, 10 and $56(17,12$, $27) \%$ of the total fresh water input into the upper estuary. Fresh water supply to the Western Scheldt occurs through the canal Gent-Terneuzen $\left(15 \mathrm{~m}^{3} \mathrm{~s}^{-1}\right)$, the discharge-sluice of lake 'Zoommeer' near Bath $\left(11 \mathrm{~m}^{3}\right.$ $\left.\mathrm{s}^{-1}\right)$ and some minor discharges from polders $\left(20 \mathrm{~m}^{3}\right.$ $\left.\mathrm{s}^{-1}\right)$.

\section{Tidal influence}

The Western Scheldt, the Sea Scheldt and the river Scheldt up to Gent and the lower parts of some tributaries are influenced by the tide. The tidal range varies throughout the estuary and the tidal rivers, and this variability is paralleled by the volumes of water transported by the tide. The Canter-Cremer number, which is defined as the ratio of the saline water volume flowing up the estuary through a given section during the flood, to the volume of fresh water flowing into the estuary above that section during a complete tidal cycle, is a measure for vertical mixing. When this ratio is large (10-1000) the estuary, or tidal river, is vertically well mixed. A ratio below 10 indicates that vertical density differences occur. In Vlissingen the mean vertical tide is $3.8 \mathrm{~m}$ whereas it is $5.0 \mathrm{~m}$ in Antwerp and $2.0 \mathrm{~m}$ in Gent. The flood volumes are respectively $100010^{6}$ and $6210^{6} \mathrm{~m}^{3}$ per tide in Vlissingen and Antwerp, the corresponding Canter-Cremer numbers are 149 and 12. Hence, the Scheldt estuary is vertically well-mixed. Only in the neighbourhood of Antwerp, occasionally a small vertical stratification may occur. Since the residence time increases quickly with increasing vertical mixing due to dilution of fresh water in a large body of sea water, the residence time of fresh water in the Scheldt estuary is high (two to three months).

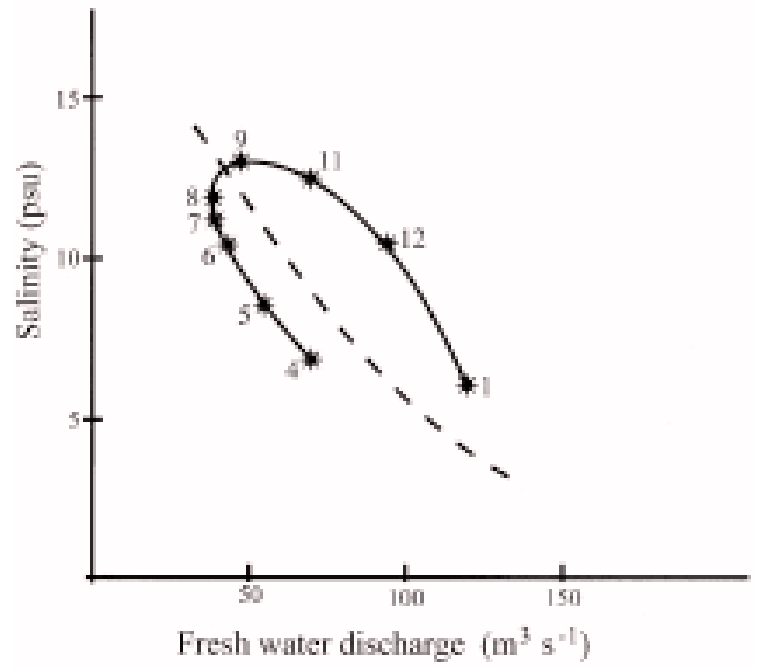

Figure 3. Observed salinities at $\mathrm{km} 40$ as a function of river flow. The broken line represents the computed salinity.

\section{Salinity}

The longitudinal salinity profile of the Scheldt estuary (the transition between fresh and salt water is particularly smooth) is primarily determined by the magnitude of the river discharge. The tidal action, on the contrary, contributes to a lesser degree (the salinity shift during a tidal period is much smaller than the salinity shift between low and high river discharge). As an example, the longitudinal chlorinity profiles for different fresh water flow rates are given in Figure 2. The yearly variation of the salinity at a given sampling station and at low tide has been plotted as a function of the river discharge (Figure 3). For the same fresh water flow rate, large differences of salinities are observed. Thus, the salinity distribution reflects here strongly the past history of the hydraulic regime. Ideally, if a steady state is established instantaneously, the relation between the salinity at a given station and the fresh water discharge should not exhibit the hysteresis shown in Figure 3.

\section{Residual current}

In the surface layer the residual velocity is always directed towards the sea, but in the bottom layer this is only the case in the upper part of the estuary (Figure 4). In the lower part of the estuary, the residual velocity is directed upstream. As a consequence there is also a region in the estuary where the net residual flow in the bottom layer equals zero. Ronday (1976) calculated the residual circulation in the Scheldt estuary with 


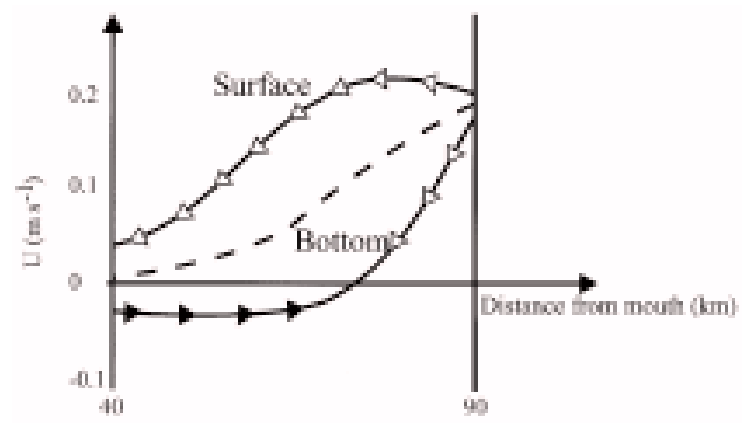

Figure 4. The residual velocity (U) at the surface and at the bottom.

a 2-D mathematical model $(\mathrm{x}-\mathrm{z})$ integrated over the width (y). According to a higher or lower fresh water flow rate the line of zero residual current is shifted downstream or upstream. At the mean river flow rate $\left(104 \mathrm{~m}^{3} \mathrm{~s}^{-1}\right)$, the point of zero residual current at the bottom is located in the zone between 2.5 and 5 psu salinity. This means that riverine and marine transported bottom material will accumulate in that area.

\section{Quantitative aspects of suspended sediments (turbidity)}

The morphological description of the Scheldt river basin is of particular interest for the transport and sedimentation of pollutants. Various pollutants interact with the finer fraction of the suspended matter, particularly the organic particles. The sediment transport in the different parts of the river basin is controlled by different transport-mechanisms. We will only discuss here the part of the Scheldt estuary between the mouth $(\mathrm{km} \mathrm{0})$ and the Rupel river ( $\mathrm{km} \mathrm{92).} \mathrm{In} \mathrm{the} \mathrm{Western}$ Scheldt (from the mouth to $55 \mathrm{~km}$ inland) spatial turbidity variations are fairly small compared to the variations observed in the upper estuary (see Figures 5a to f). This is due to the much more intense local erosionsedimentation processes in the upper estuary (see further this paper) and the highly variable suspended matter concentration in the river water end-member over a tidal cycle (Wartel, 1973; 1977; Duinker et al., 1982). On a larger time-scale, meteorological conditions and the river flow will control the turbidity values.

The longitudinal turbidity profiles show a concentration decrease in suspended matter by a factor of 4 to 5 between the upper and downstream estuarine areas. The upper estuary is therefore called the area of maximum turbidity. Compared to several other estuaries (e.g. Gironde, Loire,... ) it is noted that the maximum turbidity values are relatively low and hence the zone of maximum turbidity less pronounced.

The occurrence of a turbidity maximum has been explained in terms of a hydrodynamical model, involving non-tidal estuarine circulation of water and particles as well as tidal movements (Postma \& Kalle, 1955; Ronday, 1976; Wollast \& Peters, 1978). Non-tidal estuarine circulation processes account for collection of specific particles in the zone of increased turbidity and deposition in the bottom sediments, while alternating tidal movements account for deposition/erosion and mixing with other water bodies.

To discuss the importance of suspended matter sources in the Scheldt estuary as well as processes affecting the particle dynamics especially related to the turbidity maximum, the area Vlissingen up to Rupelmonde is subdivided in three parts (the schematic diagram of Figure 6 represents the suspended matter transport in each of the 3 zones):

Zone 10-30 psu: the Western Scheldt, extends from the mouth $(\mathrm{km} \mathrm{0})$ up to the brackish marsh of Saeftinge ( $\mathrm{km} 50$ to 55). The morphology of the estuarine bed is rather complicated by the formation of several ebb and flood channels. The maximum tidal velocity at the mouth is about $0.9 \mathrm{~m} \mathrm{~s}^{-1}$ and the residual velocity (mean over the cross section) $0.1 \mathrm{~cm} \mathrm{~s}^{-1}$. The residual bottom current is landward directed. The morphology of the Western Scheldt is also influenced by the dredging of the navigation-channels. The major part of the dredged material, which mainly consists of sand, is again dumped at various sites in the Western Scheldt maintaining the 'natural' balance of the sediment transport in this area. Only a small part of the dredged material is removed from the system and used for other purposes e.g. for landfill. The input of marine suspended matter into the lower estuary is estimated at $7910^{6} \mathrm{~kg}$ $\mathrm{y}^{-1}$ (Van Eck, 1991). This material is transported into the estuary up to the upper area as isotope measurements indicate (see the section on 'Qualitative aspects of suspended sediments'). Sedimentation amounts to $1010^{6} \mathrm{~kg} \mathrm{y}^{-1}$ (Van Eck, 1991), and occurs in the intertidal areas bordering the estuary, in particular in the brackish marsh of Saeftinge along the $50-60 \mathrm{~km}$ stretch. According to recent estimates about $50 \%$ of the fluvial suspended matter is deposited at Saeftinge, and about 35\% reaches the coastal zone (Van Eck, 1991).

The bottom sediments mainly consist of sand (coarse, medium-coarse and medium-fine) except at some outflows, such as the Gent-Terneuzen canal, and on the tidal flats. In zone 10-30 psu the amount of bottom material eroded during a tidal cycle is less impor- 

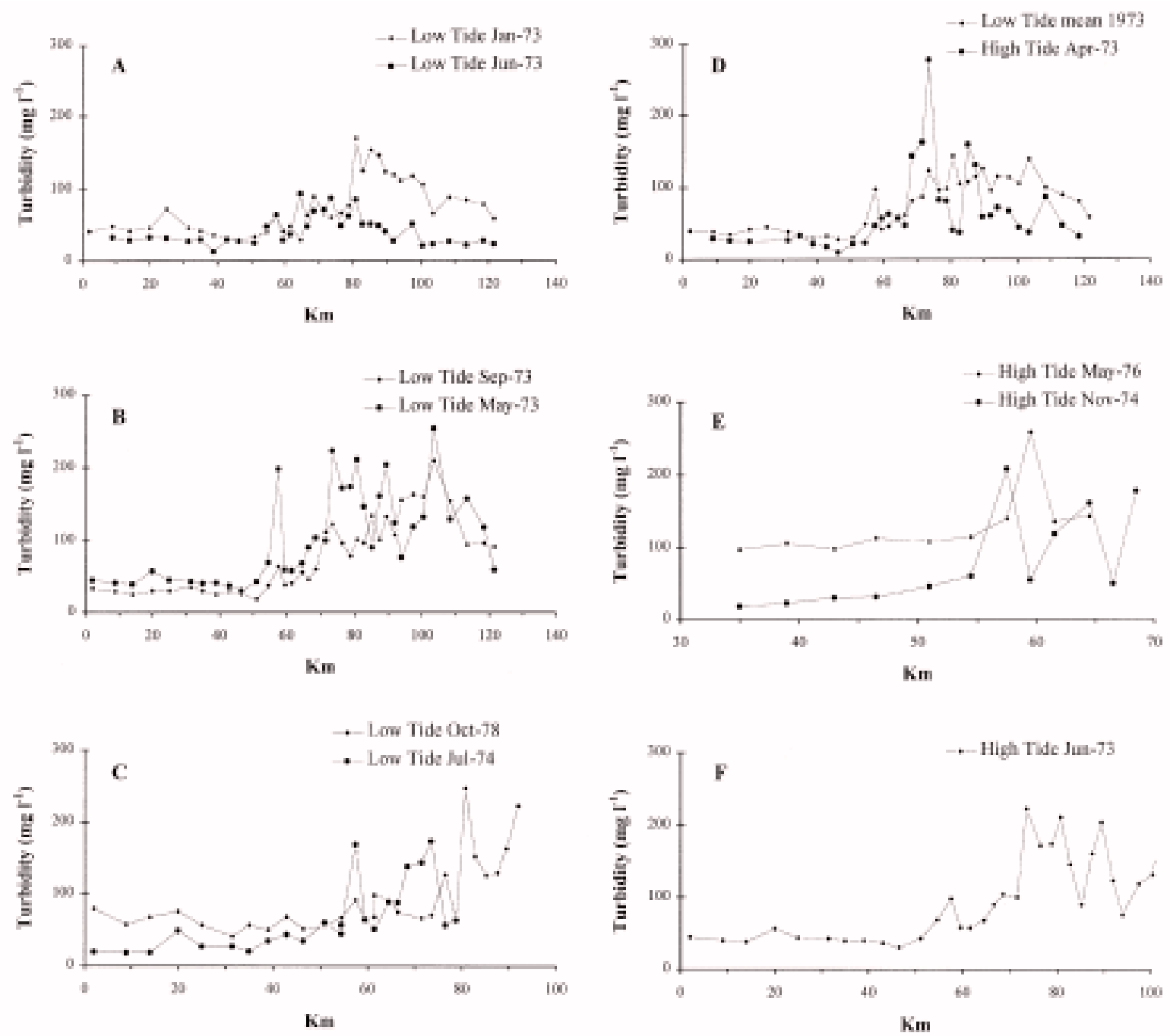

Figure 5. Turbidity profiles at high and at low tide.

tant than in zone 2-10 psu, due to the lower tidal currents and the coarser bottom material. However, at the turn of the current, half the amount of the sediment in suspension is deposited. Accordingly, a thin layer of about $0.25 \mathrm{~mm}$ is deposited at the bottom. This layer sedimentates and erodes each tide.

Observations of sand wave movements in the Western Scheldt show a relatively high mixing and exchange rate of the upper sediment layer; twice a year the upper $0.5 \mathrm{~m}$ of the sediment is brought in suspension. This process is important regarding the release of pollutants to (or uptake from) the water column.

Zone 2-10 psu: the second salinity zone starts at the brackish marsh of Saeftinghe and continues up to
Antwerp ( $\mathrm{km} \mathrm{78).} \mathrm{The} \mathrm{morphology} \mathrm{is} \mathrm{much} \mathrm{simpler}$ since the estuarine bed is restricted to one ebb/flood channel. The maximum tidal velocity is $1.1 \mathrm{~m} \mathrm{~s}^{-1}$ and the residual current (mean over the cross section) $1 \mathrm{~cm}$ $\mathrm{s}^{-1}$. In this zone there is a point where the residual current at the bottom is zero (Ronday, 1976). Bottom currents upstream (marine) and downstream (riverine) converge there (Figure 4). The sedimentation in this zone is estimated at about $28010^{6} \mathrm{~kg} \mathrm{y}^{-1}$ (Van Eck, 1991), and mainly occurs in the brackish marsh of Saeftinge.

Many sources contribute to the suspended matter composition in this zone. River-borne suspended matter and rolling bottom sediments are transported down- 


\section{Cycling Zone}

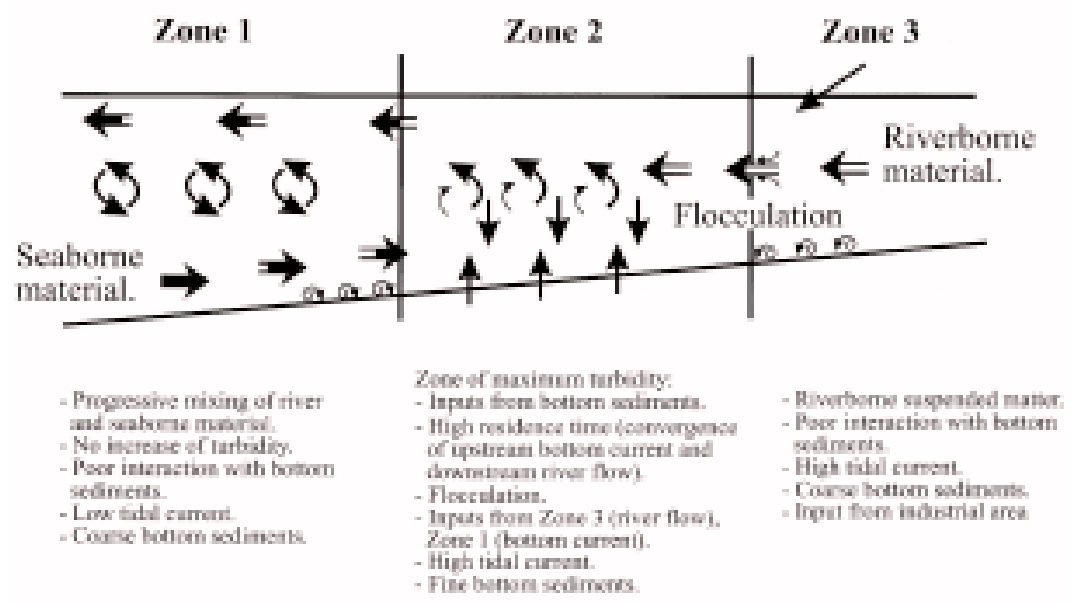

Figure 6. The qualitative suspended matter transport in the 3 zones of the Scheldt estuary.
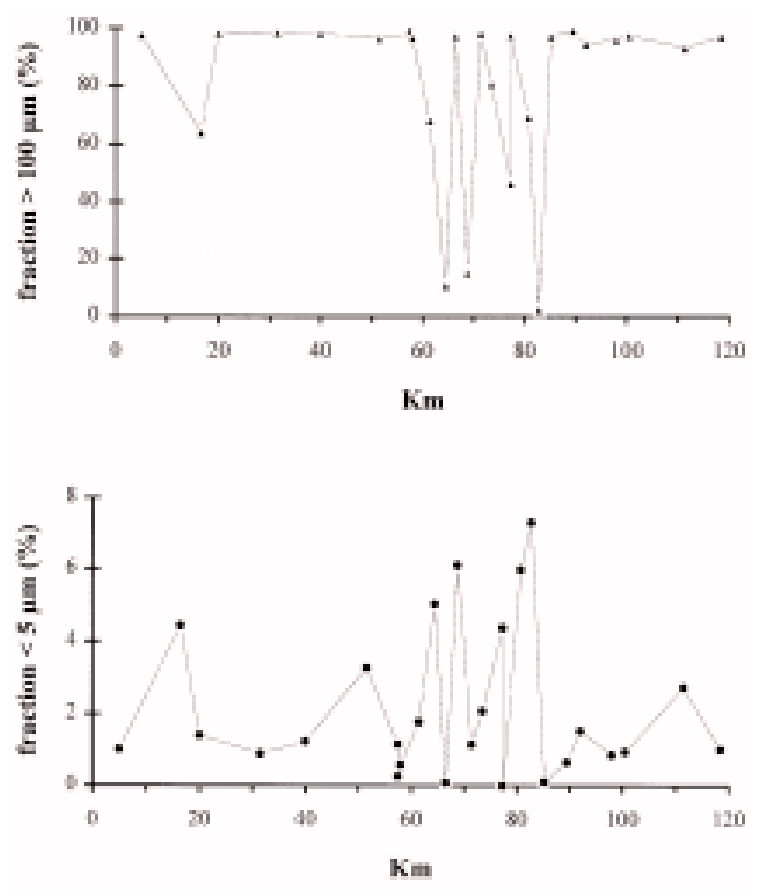

Figure 7. Grain size fractions in bottom sediments.

stream from zone $0-2$ psu. Sea-borne material is transported from zone 10-30 psu by the upstream directed saline bottom current and tidal action. At some places in the estuary one finds peaty sediments, mostly there where the riverbanks also contain such material, while at other locations, the riverbanks consist of fine sands and mud. In zone 2-10 psu, part of the continuous- ly suspended matter is influenced by the flocculation process. However, according to Meade (1972), the evidence that the effects of salt flocculation on the concentration of suspended matter can be observed in estuaries, is very limited. Fine continentally derived suspended material coagulates during early mixing (initial raise of salinity) and will more easily settle down. This zone is an exclusive site in an estuary where low density particles can be collected and trapped in suspension and in sediments despite the occurrence of strong currents. The dominant mechanism involved might well be the incorporation of fine sand particles in the aggregates under local conditions of increased concentrations of particles, thus increasing their settling velocities (Wellershaus, 1981). According to Eisma (1990), particle dynamics includes agglomeration of particles as well as deflocculation. In these processes, the particle concentration (Hwang, 1989), the presence of organics and the presence of discrete particle flocs (Wollast \& Duinker, 1982) may play an important role. An other important factor contributing to the sedimentation of finer particles in zone $2-10$ psu is related to the particular hydrodynamic conditions. In this zone, the saline upstream directed bottom current converges with the downstream directed river flow, increasing the residence time of the particles and enhancing their sedimentation. In addition, a fraction of the finer suspended matter which is exported towards zone 10-30 psu by the net seaward current sedimentates when entering that zone, because there a strong decrease in tidal current velocity occurs (the estuarine cross section strong- 
ly increases); these particles are reintroduced in zone $2-10$ psu by the upstream directed bottom current, thus also showing an enhanced residence time in that area. The combination of three factors, (1) favourable hydrodynamic conditions, (2) several fine suspended matter sources, and (3) the flocculation process, led in zone 2-10 psu to a bottom sediment that contains locally a high percentage of fine material (fine sand to mud, sometimes even a non-compacted, mobile hyperpycnal or fluid mud layer; according to Metha (1990) a fluid mud layer shows horizontal mobility, highly dissipative kinematics and turbulence damping). Granulometric analyses in the bottom sediments of the Scheldt estuary (Laurent, 1971) clearly show higher concentrations of fine particles in the bottom sediments of zone 2-10 psu (between $\mathrm{km} 80$ and $\mathrm{km} 55$ from the mouth) compared to the other zones (Figure 7). Although Van Eck (1991) suggests a high sedimentation rate for zone 2-10 psu, it does not mean that during a tidal cycle a large amount of the suspended matter is definitively trapped at the bottom. Indeed, with the typical parameter values for zone 2-10 psu (a suspended matter concentration of $200 \mathrm{mg}^{-1}$, a depth of $10 \mathrm{~m}$ and a bottom surface of $20 \mathrm{~km}^{2}$ ) it is sufficient that $0.7 \%$ of this material is trapped at the bottom per tidal cycle, to yield an accumulation rate of $28010^{6} \mathrm{~kg} \mathrm{y}^{-1}$.

High turbidities in zone 2-10 psu correspond with high tidal current velocities (stirring up of bottom sediments); in fact the denser suspended matter fraction derived from the bottom dominates in suspension practically during the entire tidal cycle, while around the turn of the current, the lowest turbidities, in fact the continuously suspended fractions, are observed. The erosion of the bottom sediments is, however, not equal during ebb and flood tide. The asymmetry between ebb and flood induces relatively more erosion than sedimentation during flood and the opposite during ebb. Turbidity measurements at low, slack water (Figures 5a to $5 \mathrm{~d}$ ) show values increasing from $\mathrm{km} 50$ (10 psu) to $\mathrm{km} 140$ (upstream zone 0-2 psu). These suspensions represent more or less the continuously suspended matter. At high water (Figures $5 \mathrm{~d}$ to $5 \mathrm{f}$ ) very high turbidities are observed essentially in zone $2-10$ psu (the turbulence in the water column during flood tide is high enough to erode or stir up bottom sediments, especially the finer bottom sediments). Erosion is also different at spring and neap tide conditions. During spring tide, erosion is very strong and distribution of the eroded particles may develop, with a time lag, over the entire water column. This differs from neap-tide conditions when erosion may be weak and distribu- tion of the eroded particles will involve a more limited layer of water above the bottom. Under such conditions, a dense suspension or even a fluid mud may be locally formed. Well known examples are found in the Gironde and Loire estuaries (Allen et al., 1974; Gallenne, 1974). High fresh water flow rates (high inputs of river-borne suspended matter) and to a lesser extent high discharges of waste water (domestic or industry) may also contribute to high turbidity values in zone 2-10 psu.

Zone 0-2 psu: the third zone or the upper part of the estuary (average salinity $2-0 \mathrm{psu}$ ) is bound by the confluence of the rivers Rupel and Scheldt ( $\mathrm{km}$ 92) and Antwerp ( $\mathrm{km} \mathrm{78).} \mathrm{The} \mathrm{same} \mathrm{morphology} \mathrm{as} \mathrm{in} \mathrm{zone} \mathrm{2-}$ 10 psu exists here. The magnitude of the maximum tidal velocity is 1.2 to $1.3 \mathrm{~m} \mathrm{~s}^{-1}$, that of the residual current (mean over the cross section) $3 \mathrm{~cm} \mathrm{~s}^{-1}$ (only seawards directed).

The quantity of suspended matter supplied by the rivers Scheldt and Rupel (Wartel, 1973, 1977; Duinker et al., 1982) is most variable (several sources are involved) and is estimated at $32010^{6} \mathrm{~kg} \mathrm{y}^{-1}$, using a mean suspended matter concentration of $100 \mathrm{mg}^{-1}$ (Wartel, 1977; D'Hondt \& Jacques, 1982). Downstream the confluence of Rupel and Scheldt, the estuary consists in a narrow channel, incised in the Boom clay, a very hard material. The velocity of the current is high (almost no sedimentation of the river-borne suspended matter occurs) and the erosion of the clay bottom is very slow. Close to $\mathrm{km} 78$ ( $2 \mathrm{psu}$ ), local bottom sediments consist of medium-fine to fine sand. Sediments in zone $0-2$ psu are eroded only when the tidal current is high and are also transported by rolling to the downstream zone. Direct discharges of domestic origin (city of Antwerp) and downstream the city by the industrial park contribute especially to the finer suspended matter fraction.

\section{Suspended matter fluxes through the estuary}

D'Hondt \& Jacques (1982) estimated the total suspended matter load produced by the whole watershed at $50810^{6} \mathrm{~kg} \mathrm{y}^{-1}\left(75310^{6} \mathrm{~kg} \mathrm{y}^{-1}\right.$ including the estuarine part). The origin of this suspended matter is as follows: $28 \%$ domestic, $27 \%$ industrial and $45 \%$ natural. Information obtained from water treatment plants learns us that for the first two sources, one third is inorganic and two third organic. Suspended matter from erosion is almost entirely inorganic. A large fraction of the organic material is degraded in the riverine system. D'Hondt \& Jacques (1982) estimated the fluvial sus- 


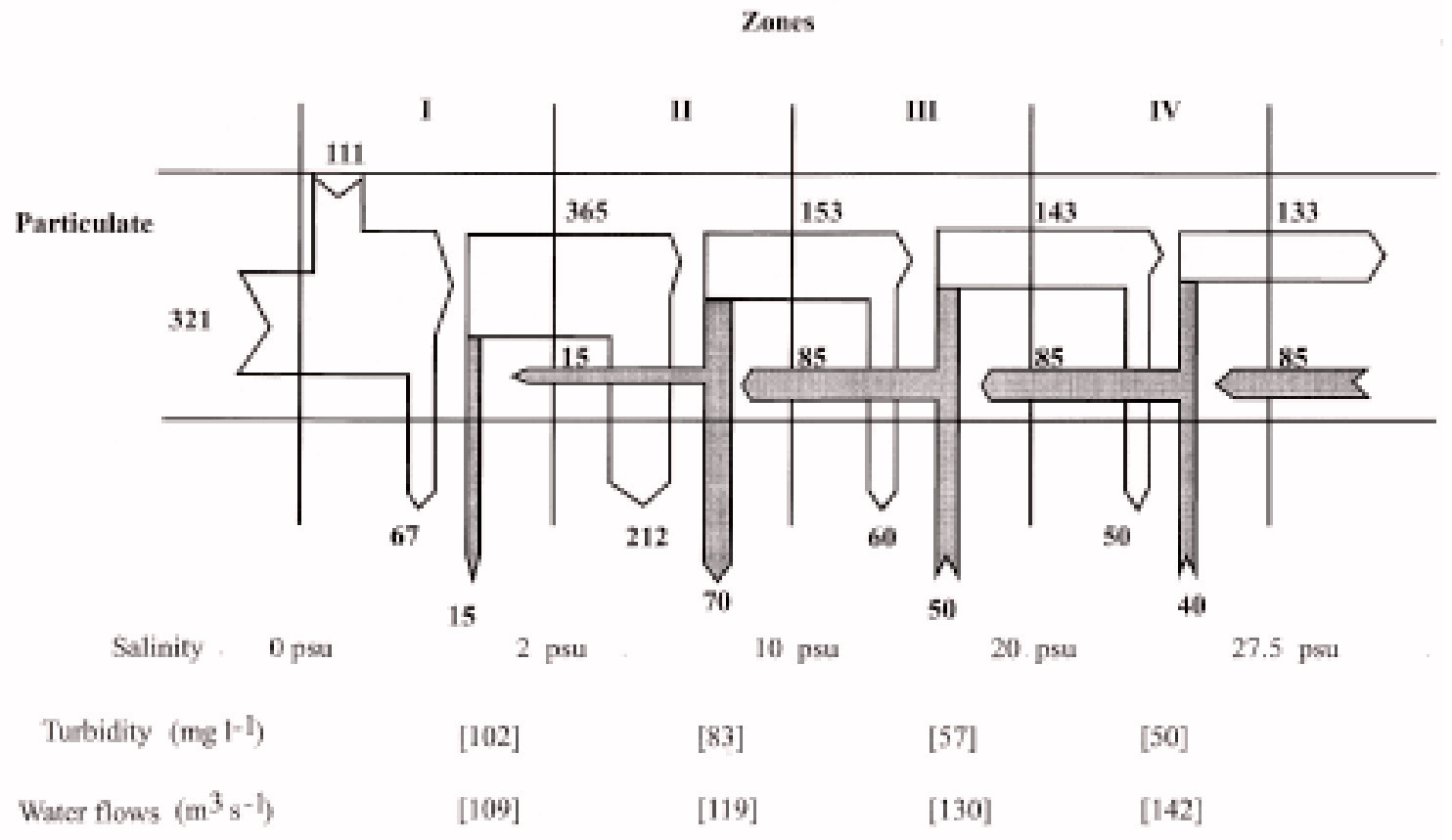

Figure 8. Sediment transport scheme (Baeyens et al., 1996). Flows in $10^{6} \mathrm{~kg} \mathrm{y}^{-1}$.

pended matter flux at the riverine/estuarine interface (Rupelmonde) at $32010^{6} \mathrm{~kg} \mathrm{y}^{-1}$, while an additional amount of $11110^{6} \mathrm{~kg} \mathrm{y}^{-1}$ is supplied by lateral inputs into the 0 to 2 psu zone. At the estuarine-sea interface an input of $7910^{6} \mathrm{~kg} \mathrm{y}^{-1}$ of suspended matter into the estuarine system has been estimated by Van Eck (1991). The flux of suspended matter into the sea is estimated at $30010^{6} \mathrm{~kg} \mathrm{y}^{-1}$ by D'Hondt and Jacques (1982), and $13610^{6} \mathrm{~kg} \mathrm{y}^{-1}$ by Van Eck (1991). According to the latter author, sedimentation in zones $0-2$ psu, 2-10 psu and above $10 \mathrm{psu}$, respectively amounts to $8310^{6} \mathrm{~kg} \mathrm{y}^{-1}, 28210^{6} \mathrm{~kg} \mathrm{y}^{-1}$ and 10 $10^{6} \mathrm{~kg} \mathrm{y}^{-1}$. Assuming a net input of fluvial suspended matter of $43210^{6} \mathrm{~kg} \mathrm{y}^{-1}$ and of marine suspended matter of $7910^{6} \mathrm{~kg} \mathrm{y}^{-1}$ and a total sedimentation of 375 $10^{6} \mathrm{~kg} \mathrm{y}^{-1}$, the net outflow of suspended matter to the sea should be $13610^{6} \mathrm{~kg} \mathrm{y}^{-1}$. Taking into account the particulate metal-mass balances in the Scheldt estuary (Baeyens et al., 1998), the sediment mass balance estimates for the downstream part of the estuary have been updated and refined (Figure 8). Nevertheless, these values are to be considered as orders of magnitude.

\section{Qualitative aspects of suspended sediments}

The low river discharge and large tidal influence results in extremely low non-tidal displacements or high residence times of water, and even larger residence times for particles in the estuary. The whole system should thus be in a quasi-equilibrium state as Duinker et al. (1982) suggested but this is only true (1) for time scales much larger than that of a tidal cycle, (2) without significant changes in the inputs from the large industrial site situated at Antwerp, and (3) without significant changes in the inputs from the sediments where the physico-chemical conditions are not necessarily constant nor identical to those in the water column. Sampling at fixed moments of the tidal cycle, at fixed salinities and/or sampling stations and in different seasons of the year is the best approach. This is, however, not always possible in practice and therefore results should be interpreted carefully in relation to a quasiequilibrium system.

One of the major processes determining the composition of the suspended particles is the estuarine mixing of the river- and sea-derived material. The mineralogy of suspended material has been described by Wollast (1973), Wartel (1977) and Van Alsenoy et al. (1989). The major components are quartz, calcite, clay miner- 

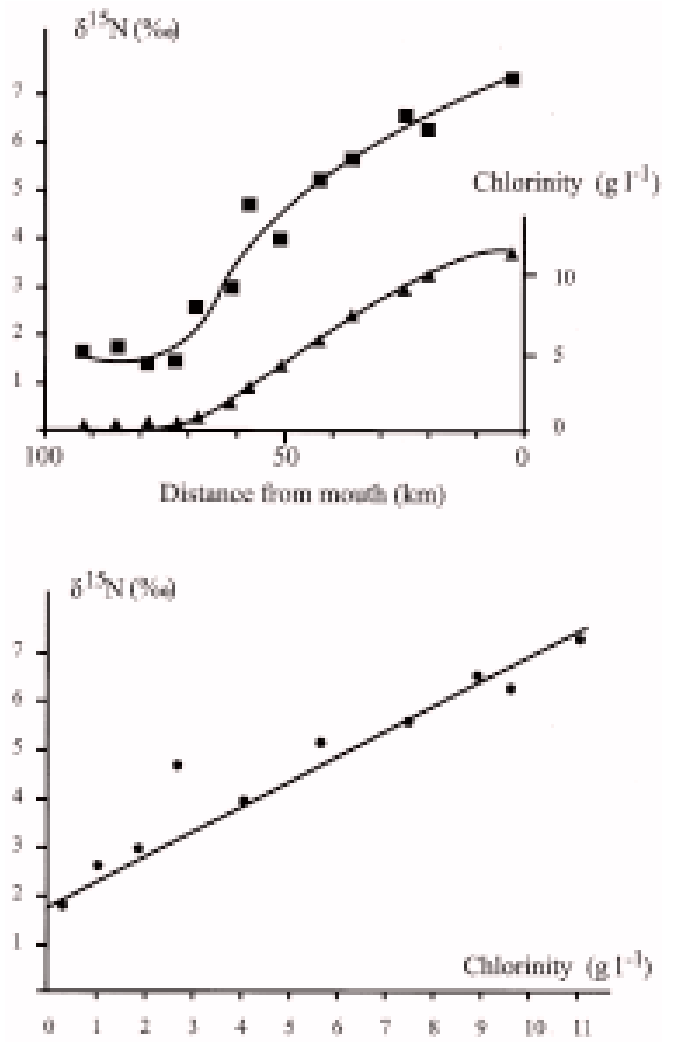

Figure 9. Longitudinal distribution of $\delta^{15} \mathrm{~N}$ in particulate organic matter (April 1982).

als (illite, montmorillonite, kaolinite and chlorite), and organic matter. Among the minor components are iron oxyhydroxides and phosphates, feldspars, dolomite and aragonite, glauconite, rutile and iron sulphides. Human activities have changed the suspended matter composition significantly (Wollast, 1988). Suspended matter resulting from domestic and agricultural activities has a high organic matter content (40-60\%). The industrial suspended load is often strongly contaminated by trace metals and contains large amounts of unusual materials such as gypsum, slag dust and metallic iron spherules. In the bottom sediments the major constituents of the silt and clay fractions are quartz, clay minerals and carbonates (Wartel, 1977).

In a study on the Scheldt estuary Salomons \& Eysink (1981) have measured the mixing ratio of marine to fluvial particulate matter by using the stable isotopic composition of carbonate minerals. They found that marine mud is transported into the estuary up to the fresh water area and that the longitudinal particulate profiles of $\mathrm{Cs}, \mathrm{Hg}, \mathrm{Cr}$ comply with
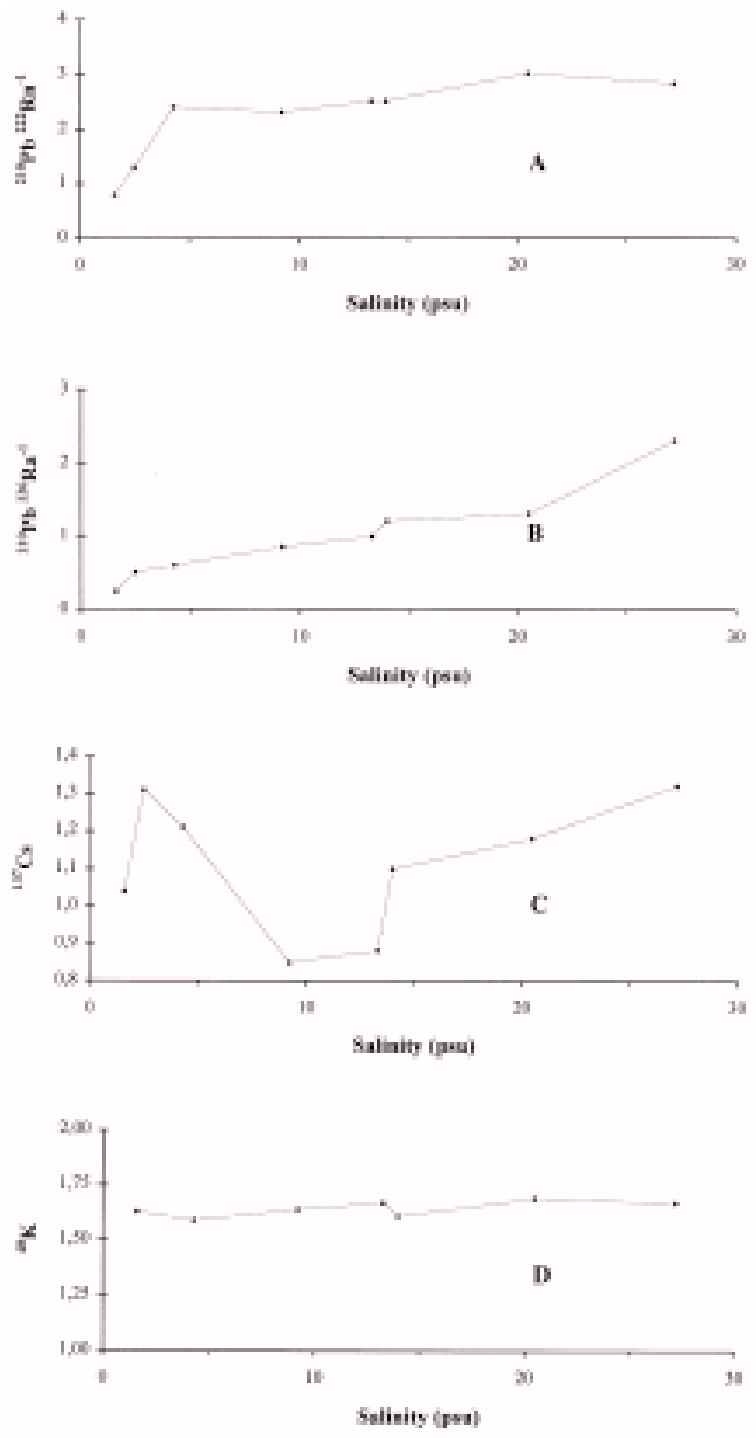

Figure 10. Longitudinal profiles of radioisotopes. Cs and K contents in $\mathrm{dpm} . \mathrm{g}^{-1}$

a conservative mixing pattern. The isotopic distribution of $\mathrm{N}$ in the particulate matter collected in the estuary reveals also some interesting facts (Mariotti, 1982). During April (Figure 9), before the spring phytoplankton bloom, the longitudinal distribution of $\delta^{15} \mathrm{~N}$ in the particulate organic matter typically corresponds to the mixing of detrital organic matter of continental origin $\left(\delta^{15} \mathrm{~N}=1.5 \%\right.$ ) with plankton of marine origin $\left(\delta^{15} \mathrm{~N}=8.5 \%\right.$ o $)$. The longitudinal profiles of ${ }^{210} \mathrm{~Pb} /{ }^{222} \mathrm{Rn},{ }^{210} \mathrm{~Pb} /{ }^{226} \mathrm{Ra},{ }^{137} \mathrm{Cs}$ and ${ }^{40} \mathrm{~K}$ are presented in Figures 10a to $10 \mathrm{~d}$. The ratio ${ }^{210} \mathrm{~Pb}$ to ${ }^{222} \mathrm{Rn}$ rapidly increases in the zone of early mixing, but tends 
to a constant value from a salinity of 4 psu on. This ratio can, as a consequence, not be used as a tracer to distinguish between the marine or continental origin of suspended sediments. However, since marine suspended matter is strongly enriched in ${ }^{210} \mathrm{~Pb}$ versus ${ }^{226} \mathrm{Ra}$, the ratio of these radioisotopes gives us an estimate of the marine fraction in that suspended matter. Besides the fact that Figure 10b confirms that marine mud is transported into the upper estuary, it appears that after an initial, rapid mixing of continentally derived material with marine material (up to about $5 \mathrm{psu}$ ), a relative more homogenous, well mixed area exists (the area 5 psu to 13 psu which corresponds to the area of maximum turbidity with larger contributions from the bottom layer and a longer residence time of the particles); in the downstream estuary we see again a progressive mixing of the suspended sediments with marine derived material.

The marine suspended matter is also enriched in ${ }^{137} \mathrm{Cs}$ (Figure 10c) but mixing with continentally derived suspended matter results in a decrease of the ${ }^{137} \mathrm{Cs}$ activity in the zone from 30 to about 10 psu. Increased activities are observed in the low salinity area, suggesting a local source: most probably the higher ${ }^{137} \mathrm{Cs}$ values are related to the nuclear power plants located at Doel, $62 \mathrm{~km}$ from the mouth. The ${ }^{40} \mathrm{~K}$ profile (Figure 10d) shows not only a conservative behaviour, but also since both end members are almost equal, an almost constant value through the estuary.

For a number of other parameters, or for some of the above mentioned ones at other periods of the year (e.g. $\left.\delta^{15} \mathrm{~N}\right)$, no conservative mixing was observed. Two global transformation zones in the estuary are responsible for the non-conservative behaviour of those variables: a geochemical filter (including microbial processes controlling the redox potential) in the upstream estuary and a biological filter in the lower estuary.

\section{Upstream estuary: the geochemical filter}

The organic carbon load of the Scheldt basin is very high $\left(290 \times 10^{9} \mathrm{~g}-\mathrm{C} \mathrm{y}^{-1}\right.$, Wollast, 1982). Most of this organic matter is degraded and respired in the river before the fresh water reaches the estuary. However, the organic matter concentrations entering the estuary are still high. The mean dissolved matter concentration (DOC) is $7 \mathrm{mg}-\mathrm{C}^{-1}$ and the particulate organic matter concentration reaches $15 \mathrm{mg}-\mathrm{C}^{-1}$ whereas in unpolluted rivers these values are respectively estimated at 3 and $2 \mathrm{mg}-\mathrm{C}^{-1}$ (Meybeck, 1982). The high

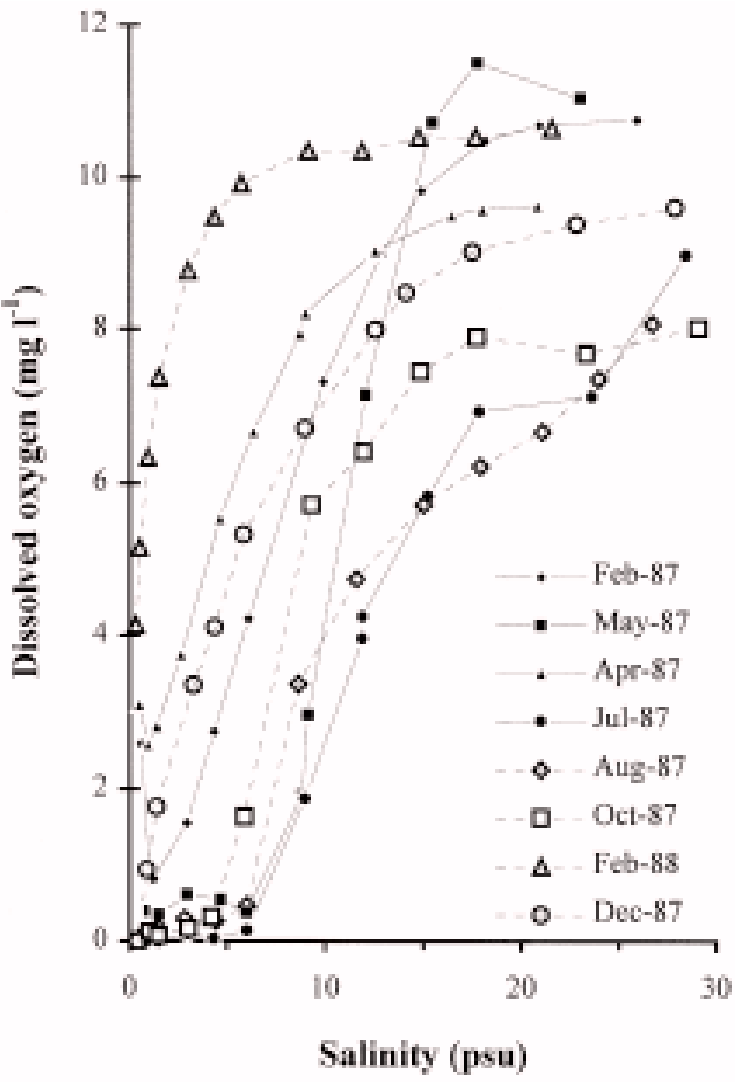

Figure 11. Seasonal $\mathrm{O}_{2}$ variations.

nutrient concentrations create high productivity in the riverine system with values of $30 \mathrm{mg} \mathrm{l}^{-1}$ chlorophyll-a (Van Eck et al., 1991) but up to $100 \mathrm{mg} \mathrm{l}^{-1}$ in May 1978 (Wollast, 1982). The chlorophyll-a values during the latter cruise dropped to almost zero in the zone of turbidity maximum, which in that period of the year is yet strongly depleted in oxygen.

As a consequence of the high organic load entering the estuary, the upper estuary is suboxic in winter, but becomes progressively anoxic when the season proceeds. Simultaneously the suboxic/anoxic area extends. The seasonal variations of the oxygen content at different locations in the estuary in 1982 are shown in Figure 11. In the upper estuary, oxygen may be completely exhausted in the summer months. The longitudinal oxygen profiles as a function of salinity are shown in Figures 12 and 13 for 1982-1983 and 1988 respectively. It is worthwhile to stress that the oxygen profiles presented here are only representative for the years indicated, (1) because the estuarine system is continuously in evolution and (2) the construction 


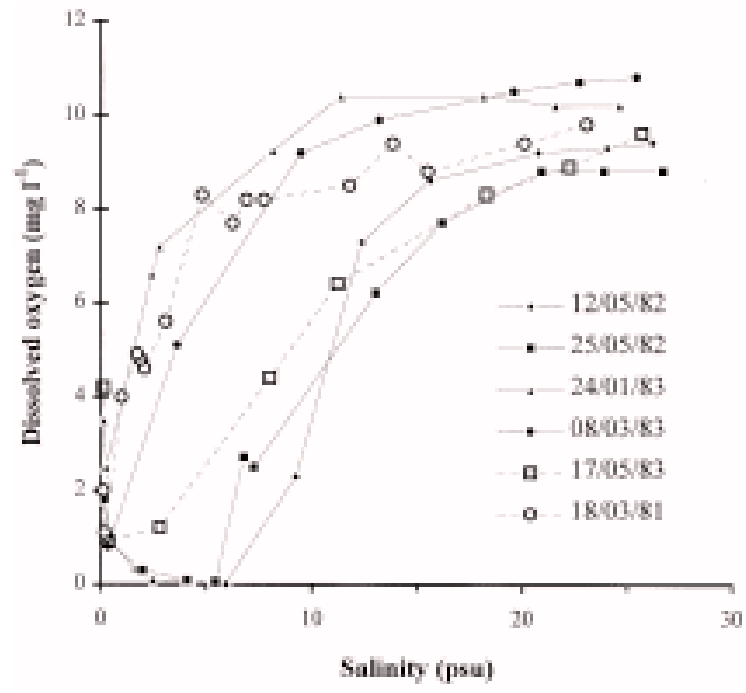

Figure 12. Longitudinal $\mathrm{O}_{2}$ profiles in the period 1981-1983.

of water treatment plants changed the organic carbon loads.

In winter period the physicochemical conditions in the upper estuary are: high amounts of DOC and nutrients including carbonates, a high turbidity, and a suboxic water column. Under these conditions several processes influence the dissolved/solid distribution of the trace metals:

- adsorption/precipitation: positive deviations from the mixing curve, i.e. precipitation/adsorption processes were found for $\mathrm{Fe}, \mathrm{Mn}$ and $\mathrm{P}$ (and may be valid for trace metals too) in the Scheldt estuary (Salomons \& Eysink, 1981).

- Coprecipitation and adsorption on ironhydroxides: a coupling between sedimentary redox processes and enrichment of iron and manganese in North Sea suspended matter has been reported by Dehairs et al. (1989). A similar study was carried out on Scheldt sediments by Panutrakul \& Baeyens (1991) and Baeyens et al. (1991), and they observed reprecipitation of iron and manganese oxyhydroxides at the oxic/suboxic interface in the sediments. Zwolsman (1992) confirms the enrichment of iron and manganese in the suspended matter of the high turbidity zone in the Scheldt by typical pore water gradients across the sediment-water interface in that area of $421 \mathrm{mM} \mathrm{cm}^{-1}$ for $\mathrm{Fe}$ and $45 \mathrm{mM} \mathrm{cm}^{-1}$ for Mn.

- precipitation of dissolved organic carbon (DOC): another mechanism is the flocculation process of dissolved organics, removing all associated
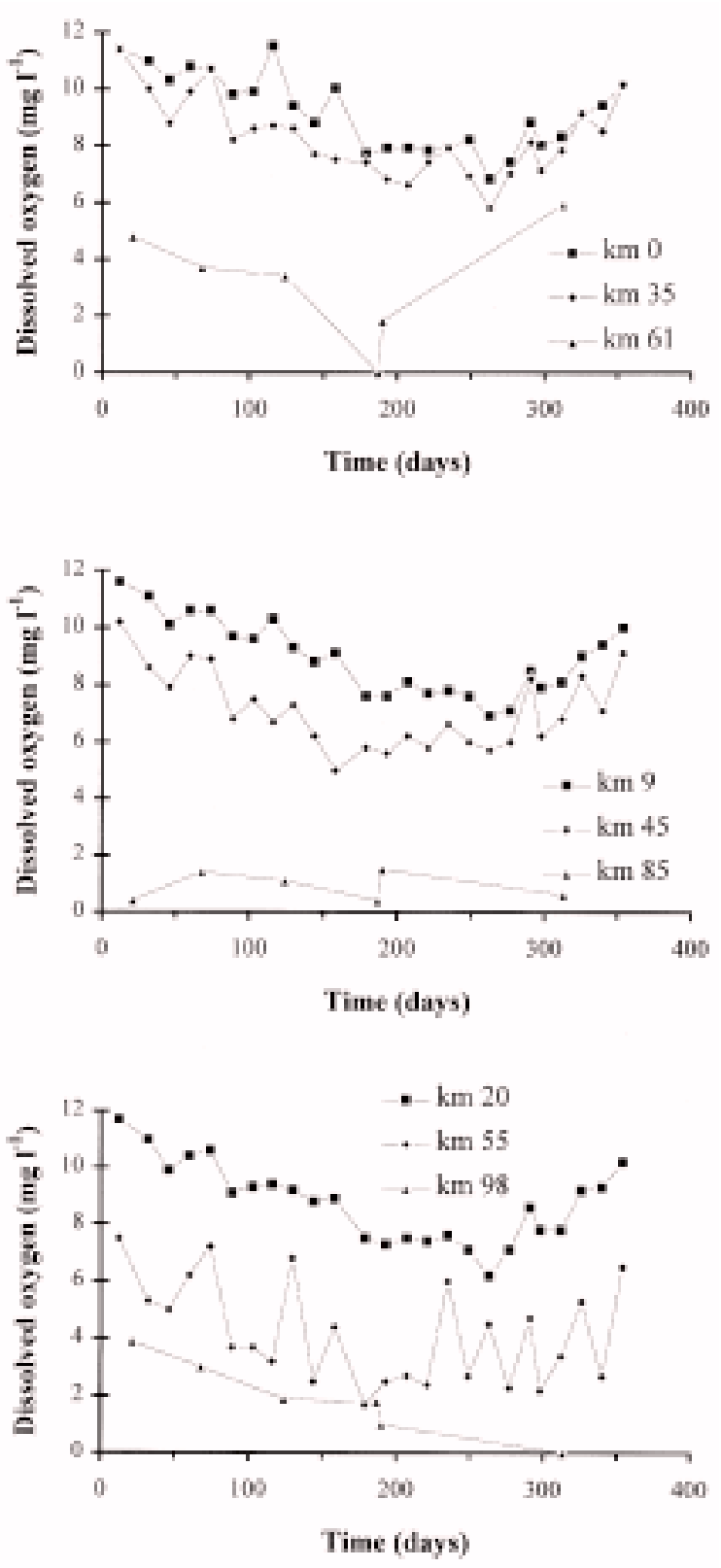

Figure 13. Longitudinal $\mathrm{O}_{2}$ profiles in the period 1987-1988.

trace metals from solution (Zwolsman, 1992; Sholkovitz, 1976).

- Oxidation of resuspended metal sulphides: in the reduced sediments in zone $2-10 \mathrm{psu}$, the oxidisable fraction (metal sulphides and metals bound to the organic matter) constitutes a major fraction according to the general accepted sequential extraction schemes (Panutrakul \& Baeyens, 1991; Baeyens et al., 1991). Due to the strong tidal action and the 
presence of fine muddy sediments, metal sulphides can be resuspended.

The overall result of these processes on the metal distribution is generally a depletion in the dissolved phase and an enrichment in the particulate phase.

Downstream the zone of the turbidity maximum, desorption and oxidation processes may increase the dissolved metal concentrations. The increase of the dissolved cation content when the river water is progressively mixed with sea water affects the composition of the suspended matter, especially with respect to those compounds exhibiting exchange properties. In addition, increased inorganic ligand concentrations such as $\mathrm{Cl}^{-}$are capable to keep some trace metals such as cadmium and mercury, forming chloro-complexes of a relative high stability (Förstner et al., 1982), in solution. On the other hand, a progressive oxidation of metal sulphides and/or metals bound to particulate organic matter resuspended in zone $2-10 \mathrm{psu}$, can also enhance the dissolved metal concentrations.

In summer period, the upstream estuary is anoxic. Literature suggests that precipitation of metal sulphides is involved (Duinker et al., 1982; Zwolsman, 1992); the latter authors reported the presence of sulphide in anoxic river water samples of the Scheldt. Sulphide precipitation can present, in addition to the previously mentioned processes, a removal process of dissolved metals in summer in the upper estuary.

\section{Lower estuary: the biological filter}

In the anoxic zone of the estuary, the chlorophyll- $a$ concentration is high as a result of the nearly complete absence of herbivores (Figure 14). The plankton bloom in the downstream estuary is, however, less pronounced than in the riverine system due to a dilution of the nutrient concentrations. Earlier in this paper, $\delta^{15} \mathrm{~N}$ in particulate organic matter indicated a conservative mixing of marine and continental derived suspended sediments. This relationship was observed in April, before the plankton bloom. However, during the period of high phytoplankton activity in the downstream estuary, a considerable increase of $\delta^{15} \mathrm{~N}$ in the particulate organic matter is observed. During the flowering period (April-September) autochtonous phytoplankton contributes up to $50 \%$ of the total suspended matter concentration in the lower estuary (Mariotti et al., 1984). This local enrichment perturbs the previously observed conservative mixing pattern of $\delta^{15} \mathrm{~N}$. According to Wollast (1982), this phenomenon is due

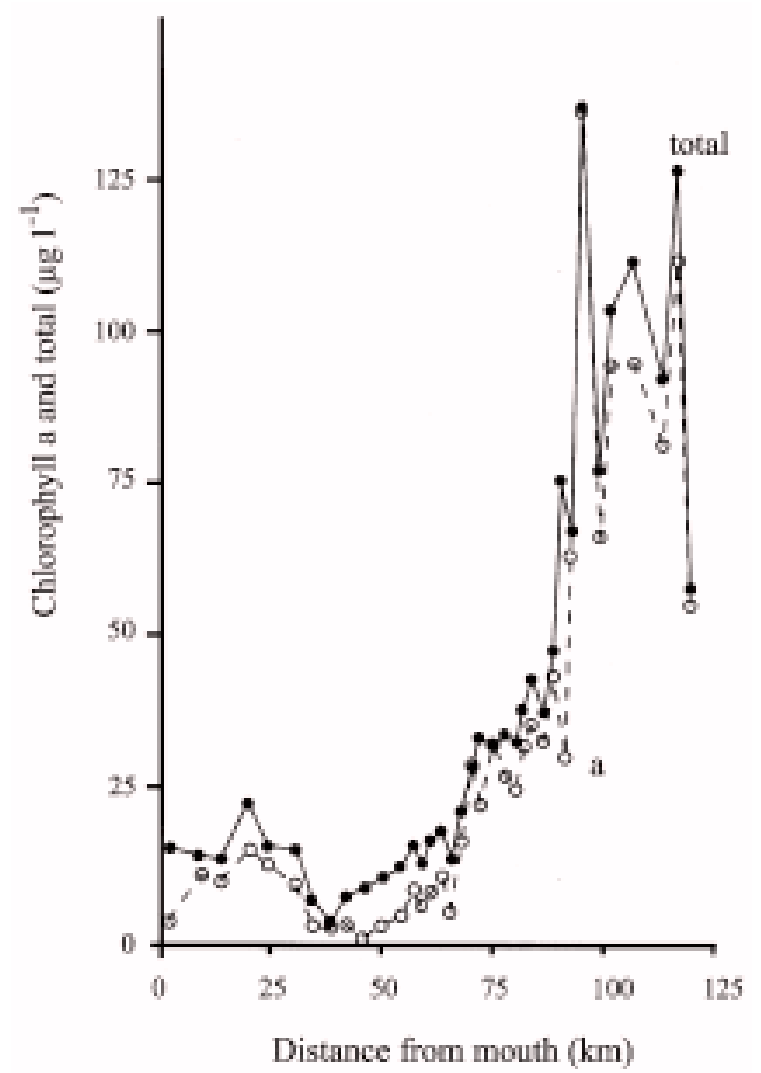

Figure 14. Longitudinal chlorophyll profiles.

to the nitrification process and the progressive enrichment of ammonia in $\delta^{15} \mathrm{~N}$.

Some metals are actively incorporated during phytoplankton growth. Indeed, Zwolsman (1992) observed a very good correlation between dissolved silica and dissolved $\mathrm{Cd}$ and $\mathrm{Zn}$ in the lower estuary over the year. Silica is the nutrient which is predominantly assimilated by the phytoplankton (diatoms) in the Scheldt estuary.

\section{Conclusion}

The general concepts on hydrology, sediment transport, suspended matter composition and biological activity in the Scheldt described here above, are basic requirements for a better understanding of the trace metal behaviour in that estuary. It appears that he Scheldt estuary is a unique polluted system due to the particular physicochemical conditions in the upstream estuary, especially the high turbidity, high sedimentation, oxygen depletion and the relatively large inputs 
of metals. The behaviour of $\mathrm{Cd}, \mathrm{Cu}, \mathrm{Hg}, \mathrm{Pb}$ and $\mathrm{Zn}$, in relation to these characteristics, is discussed in related papers.

\section{Acknowledgement}

The authors are particularly indebted to the Ministry of Science Policy for their continuous and lasting interest regarding oceanographic research, and more specifically for the financial support they offered us during the periods 1970-1982 and 1990-1996. We are also grateful to the Management Unit of the Mathematical Model North Sea and Scheldt Estuary for offering ship-time on the MS Mechelen and the MS Belgica.

\section{References}

Allen, G. P., P. Castaing \& A. Klingebiel, 1974. Suspended sediment transport and deposition in the Gironde estuary and adjacent shelf. Mem. Inst. Geol. Bassin Aquitaine 7: 27-36.

Baeyens, W., G. Gillain, F. Ronday \& F. Dehairs, 1987. Trace metals in the eastern part of the North Sea. II: Flows of $\mathrm{Cd}, \mathrm{Cu}, \mathrm{Hg}, \mathrm{Pb}$ and $\mathrm{Zn}$ through the coastal area. Oceanol. Acta 10: 301-309.

Baeyens, W., S. Panutrakul, M. Leermakers, J. Navez \& M. Elskens, 1991. Geochemical processes in sandy and muddy sediments. Geo-Marine Lett. 11: 188-193.

Baeyens, W., F. Monteny, R. Van Ryssen \& M. Leermakers, 1998. A box-model of metal flows through the Scheldt estuary (19811983 and 1992-1995). Hydrobiologia 366: 109-128.

D'Hondt, P \& T. G. Jacques, 1982. Gesuspendeerde materie in de Schelde. Evaluatie van een onderzoek van de ULB voor het ministerie van Volksgezondheid. Water 4: 133-135.

Dehairs, F., W. Baeyens \& D. Van Gansbeke, 1989. Tight coupling between enrichment of iron and manganese in North Sea suspended matter and sedimentary redox processes: evidence for seasonal variability. Estuar. coast. Shelf S. 29: 457-471.

Duinker, J. C., R. F. Nolting \& D. Michel, 1982. Effects of salinity, $\mathrm{pH}$ and redox conditions on the behaviour of $\mathrm{Cd}, \mathrm{Zn}, \mathrm{Ni}$ and $\mathrm{Mn}$ in the Scheldt estuary. Thalassia Jugoslavica 18: 191-202.

Eisma, D., 1990. Particle size analysis of suspended material. In S. Wartel (ed.), Towards a Definition of Mud, Royal Belgian, Institute for National Sciences, Brussels, Belgium, 32.

Förstner, U., W. Calmano \& J. Schoer, 1982. Heavy metals in bottom sediments and suspended material from the Elbe, Weser and Ems estuaries and from the German Bight (south eastern North Sea). Thalassia Jugoslavica 18: 97-122.

Gallenne, B., 1974. Study of fine material in suspension in the estuary of the Loire and its dynamic grading. Estuar. coast. Shelf S. 2: 261-272.

Hwang, K.-N., 1989. Erodibility of fine sediment in wave dominated environments. M.S. Thesis, University of Florida, Gainesville, $156 \mathrm{pp}$.

Laurent, E., 1971. Etude minéralogique de l'envasement de l'Escaut. Rapport $\mathrm{N}^{\circ} 1$, Ecole Royale Militaire, Bruxelles, $56 \mathrm{pp}$.

Mariotti, A., 1982. Apports de la geochimie isotopique a la connaissance du cycle de l'azote. These de doctorat, Universite Pierre et Marie Curie, Paris 6.

Mariotti, A., C. Lancelot \& G. Billen, 1984. Natural isotopic composition of nitrogen as a tracer of origin for suspended organic matter in the Scheldt estuary. Geochim. Cosmochim. Acta 48: 549-555.

Meade, R. H., 1972. Transport and deposition of sediments in estuaries. Geol. Soc. Mem. 133: 91-120.

Metha, A. J., 1990. Defining fluid mud in a dynamic environment. In S. Wartel (ed.), Towards a Definition of Mud, Royal Belgian Institute for National Sciences, Brussels, Belgium, 58-59.

Meybeck, M., 1982. Carbon, Nitrogen and Phosphorus transport by rivers. Am. J. Sci. 282: 401-450.

Panatrakul, S. \& W. Baeyens, 1991. The behaviour of heavy metals in a mud flat of the Scheldt estuary, Belgium. Mar. Pollut. Bull. 22: $128-134$.

Postma, H. \& K. Kalle, 1955. Die Entstehung von Trübungszonen im Unterlauf der Flüsse, speziell im Hinblick auf die Verhältnisse in der Unterelbe. Deutsche Hydrografische Zeitung 8: 138-144.

Ronday, F., 1976. Modèles hydrodynamiques. In J. C. J. Nihoul (ed.), Projet Mer, Rapport Final, Le Ministère de la Programmation de la Politique Scientifique, Brussels, Vol. 3, 270 pp.

Saeijs, H. L. F., 1977. De Westerschelde een milieu in beweging. De natuurwetenschappelijke waarde van de Westerschelde en de bedreigingen daarvan. Rijkswaterstaat, Middelburg, the Netherlands, $32 \mathrm{pp}$.

Salomons, W. \& W. D. Eysink, 1981. Pathways of mud and particulate trace metals from rivers to the southern North Sea. In S. D. Nio et al. (eds), Holocene Marine Sedimentation in the North Sea Basin. Blackwell, Oxford: 429-450.

Sholkovitz, E. R., 1976. Flocculation of dissolved organic and inorganic matter during the mixing of river water and sea water. Geochim. Cosmochim. Acta 40: 831-845.

Van Alsenoy, V., A. Van Put, P. Bernard \& R. Van Grieken, 1989. Chemical characterization of suspensions and sediments in the North Sea and Scheldt estuary. ICES, C.M. 1989/E:31, The Hague, $18 \mathrm{pp}$.

Van Eck, G. T. M., 1991. De ontwikkeling van een waterkwaliteitsmodel voor het Schelde-estuarium. Water 61: 215-218.

Van Eck, G. T. M., N. De Pauw, M. Van Den Langenbergh \& G. Verreet, 1991. Emissies, gehalten, gedrag en effecten van microverontreinigingen in het stroomgebied van de Schelde en het Scheldeestuarium. Water 61: 215-218.

Wartel, S., 1973. Variations in concentration of suspended matter in the Scheldt estuary. Bull. Inst. r. Sci. nat. Belg. 49: 1-11.

Wartel, S., 1977. Composition, transport and origin of sediments in the Scheldt estuary. Geol. Mijnbouw 56: 219-233.

Wellershaus, S., 1981. Turbidity maximum and mud shoaling in the Weser estuary. Arch. Hydrobiol. 29: 161-198.

Wollast, R., 1973. Origine et mecanisme de l'envasement de l'estuaire de l'Escaut. Rapport de synthese, Ministere des Travaux Publics, Borgerhout (Belgium), 140 pp.

Wollast, R., 1982. Behaviour of organic carbon, nitrogen and phosphorous in the Scheldt estuary. Thalassia Jugoslavica 18: 11-34.

Wollast, R., 1988. The Scheldt estuary. In W. Salomons et al. (eds), Pollution of the North Sea: an Assessment. Springer-Verlag, Berlin: 183-193.

Wollast, R. \& J. C. Duinker, 1982. General methodology and sampling strategy for studies on the behaviour of chemicals in estuaries. Thalassia Jugoslavica 18: 471-491.

Wollast, R. \& J. J. Peters, 1978. Biogeochemical properties of an estuarine ecosystem: the river Scheldt. In E. Goldberg (ed.), Biogeochemistry of Estuarine Sediments, Unesco, Paris: 279-293.

Zwolsman, J. J. G., 1992. Behaviour of trace metals in the Scheldt estuary. Ph.D. Thesis, University of Utrecht. 